\title{
Aqueous extract of Cleistanthus collinus induces activity of peroxidase and catalase in the seedlings of cucumber and chilli
}

\author{
Monal R. Kadoo ${ }^{1}$ and Rupesh S. Badere ${ }^{1,2, *}$ \\ ${ }^{1}$ Department of Botany, Hislop College, Temple Road, Civil Lines, Nagpur 440 001, India \\ ${ }^{2}$ Present address: Department of Botany, RTM Nagpur University, MJP Educational Campus, Amravati Road, Nagpur 440 033, India
}

We studied the effect of aqueous extracts of $\mathrm{Azadi-}$ rachta indica, Calotropis procera, Cleistanthus collinus, Dalbergia sissoo, Datura inoxia and Lantana camara on induction of peroxidase (POD) and catalase (CAT) in cucumber and chilli seedlings. The extract of $C$. collinus, exhibited a profound effect by inducing maximum activity of POD and CAT in both the crop species. Therefore, we fractionated the extract of C. collinus over silica gel column using $90 \%, 45 \%$ and $0 \%$ aqueous methanol. The fraction eluted by $90 \%$ methanol (fraction 1) showed bioactivity by inducing POD and CAT activity. Also, the extract of $C$. collinus and fraction 1 modulated the isozyme profile of both the enzymes. In addition, they also increased $\mathrm{H}_{2} \mathrm{O}_{2}$ content in the seedlings, suggesting the triggering of defence mechanism in the seedlings. The findings of the present study suggest the possibility of developing an organic crop protection agent using $C$. collinus.

Keywords: Bioactives, crop protection, induced resistance, isozymes, plant extract.

PROTECTION of crops from pests and pathogens is an effective way to boost their yield. However, the use of synthetic chemicals results in environmental pollution. Therefore, deployment of biological agents, which trigger the intrinsic defence mechanism of the plants and prevent disease attack on crops, is recommended. Such agents include plant growth-promoting rhizobia (PGPRs) and plant extracts, which are capable of eliciting defence responses in the plants, thereby conditioning them with resistance ${ }^{1}$. Extracts of various plants have been proved to induce systemic acquired resistance (SAR); for example, Agapanthus africanus ${ }^{2}$, Zimmu (Allium cepa $\times$ Allium sativum $)^{3}$, Allium alliceum ${ }^{3}$, Adathoda vasica ${ }^{1}$ and Cinnamomum cassia ${ }^{4}$.

Therefore, we aimed to identify a few plants having the ability to trigger defence gene expression in crop plants. This would enable developing a 'green' resistance conditioner for the crops. Cucumber and chilli are widely cultivated and consumed the world over. These crops are

*For correspondence. (e-mail: rsbadere@nagpuruniversity.nic.in) also susceptible to various diseases ${ }^{5,6}$. Hence, induction of defence gene expression by the plant extracts was studied in these two crops. We have recently reported modulation of the activity of chitinases and glucanases by the aqueous extract of Cleistanthus collinus in cucumber and chilli ${ }^{7}$. The present study reports the induction of POD and CAT in seedlings of cucumber and chilli by the extracts of wild plants.

\section{Materials and methods}

\section{Collection of plants}

Nagpur district, Maharashtra is located in Central India between $20^{\circ} 35^{\prime}-21^{\circ} 44^{\prime} \mathrm{N}$ and $78^{\circ} 15^{\prime}-79^{\circ} 40^{\prime} \mathrm{E}$. Azadirachta indica, Calotropis procera, Cleistanthus collinus, Dalbergia sissoo, Datura inoxia and Lantana camara are common all over the region in protected and unprotected forests as well as in areas having human settlements. The aerial parts of these plants were collected from February to May and washed with tap water, shade-dried and pulverized. The powder was stored in airtight plastic pouches under cool and dry conditions until further use. The seedlings of cucumber and chilli were elicited with aqueous extract of these plants.

\section{Elicitation of seedlings with plant extract and fractionated extract of $C$. collinus}

The seedlings of cucumber (Cucumis sativus L. var. Mohini 186-51585) and chilli (Capsicum annuum L. var. Pusa Jwala 172-25624) were elicited with aqueous extract of the plants. The extract was prepared essentially as described earlier ${ }^{7}$. The seedlings of cucumber and chilli were raised from the seeds gifted by Ankur Seeds Pvt Ltd, Nagpur, as described by Kadoo and Badere ${ }^{7,8}$.

The etiolated seedlings of cucumber and chilli were aseptically sprayed with plant extract or fractions of the extract of $C$. collinus and fixed in liquid nitrogen. The seedlings were fixed at $0,48,72$ and $96 \mathrm{~h}$ after elicitation with the plant extract to assay the POD and CAT activity. Similarly, on elicitation with fractions of $C$. collinus 
extract, the seedlings were fixed at 0 and $72 \mathrm{~h}$ after elicitation to assay the enzyme activity and develop the isozyme profile of POD and CAT.

Elicited seedlings were fixed in liquid nitrogen between 45 and $75 \mathrm{~h}$ after elicitation at a interval of $5 \mathrm{~h}$ to study the effect of elicitation with $C$. collinus extract and its fraction 1 on hydrogen peroxide $\left(\mathrm{H}_{2} \mathrm{O}_{2}\right)$ content.

The seedlings sprayed with sterile distilled water served as control.

\section{Fractionation of the extract of C. collinus}

The extract of $C$. collinus was fractionated by sequential elution with $90 \%$ methanol, $45 \%$ methanol and distilled over silica gel column, strictly following the procedure described earlier ${ }^{7}$.

\section{Enzyme assay}

The activity of POD and CAT was determined in cotyledonary leaves, hypocotyl and root of the seedling, as described by Sadasivam and Manickam ${ }^{9}$.

$P O D$ assay: One gram of frozen tissue was crushed with $3 \mathrm{ml}$ of extraction buffer $(0.1 \mathrm{M}$ phosphate buffer, $\mathrm{pH}$ 7.0) in a precooled mortar and pestle kept in an ice bucket. The homogenate was centrifuged at $10,000 \mathrm{rpm}$ for $15 \mathrm{~min}$ at $5^{\circ} \mathrm{C}$ and the supernatant used as enzyme source. The $4 \mathrm{ml}$ of the test mixture consisted of extraction buffer, $0.1 \mathrm{ml}$ of crude enzyme extract, $1 \mu \mathrm{mol}$ of guaiacol and $0.369 \mu \mathrm{mol}$ of hydrogen peroxide. The contents were mixed and immediately introduced in the UV-Vis spectrophotometer. Absorbance was recorded at $436 \mathrm{~nm}$ against a blank prepared by mixing all the ingredients of the test mixture, except $\mathrm{H}_{2} \mathrm{O}_{2}$. First, the absorbance was allowed to increase by 0.05 and then the time(s) needed to increase the absorbance by 0.1 was noted. POD activity was calculated according to the following formula

$$
\text { POD activity (units } / \mathrm{mg} \text { of protein })=\frac{3.18 \times 0.1 \times p}{6.39 \times \Delta t \times 0.1},
$$

where $p$ is the amount of protein (mg) present in the enzyme extract and $\Delta t$ is the time (s) taken to increase the absorbance by 0.1 .

CAT assay: One gram of frozen tissue was extracted with $20 \mathrm{ml}$ of extraction buffer $(0.0067 \mathrm{M}$ phosphate buffer, $\mathrm{pH} \mathrm{7.0)}$ and centrifuged at $10,000 \mathrm{rpm}$ for $10 \mathrm{~min}$. The supernatant was used as crude enzyme extract. The $4 \mathrm{ml}$ of assay mixture consisted of $42.18 \mu \mathrm{mol}$ of $\mathrm{H}_{2} \mathrm{O}_{2}$ in phosphate buffer $(0.067 \mathrm{M}, \mathrm{pH} 7.0)$, to which $10 \mu \mathrm{l}$ of crude enzyme extract was added. Absorbance of the assay mixture was read against phosphate buffer $(0.067 \mathrm{M}, \mathrm{pH}$
$7.0)$ at $240 \mathrm{~nm}$. The time(s) needed $(\Delta t)$ for the absorbance to decrease from 0.45 to 0.40 was recorded. CAT activity was determined according to the following formula

$$
\text { CAT activity (units } / \mathrm{mg} \text { of protein) }=\frac{\Delta t \times 10}{0.01 \times p},
$$

where $p$ is the amount of protein $(\mathrm{mg})$ in the crude enzyme extract.

The protein content in crude enzyme extract was determined according to Bradford's method ${ }^{10}$.

\section{Determination of $\mathrm{H}_{2} \mathrm{O}_{2}$ content in the elicited seedlings}

To determine the $\mathrm{H}_{2} \mathrm{O}_{2}$ content, $250 \mathrm{mg}$ of tissue was extracted with $5 \mathrm{ml}$ of $0.1 \%(\mathrm{w} / \mathrm{v})$ trichloroacetic acid, $10 \mathrm{ml}$ of $1 \mathrm{M}$ potassium iodide and $2 \mathrm{ml}$ of phosphate buffer $(10 \mathrm{mM}, \mathrm{pH} 7.0)$ in a chilled mortar and pestle over an ice bath. The homogenate was centrifuged at $10,000 \mathrm{rpm}$ for $15 \mathrm{~min}$ at $4^{\circ} \mathrm{C}$. Later, absorbance of the supernatant was measured at $390 \mathrm{~nm}$ against blank ${ }^{11}$. The amount of $\mathrm{H}_{2} \mathrm{O}_{2}$ present in the extract was then determined from the standard curve and expressed as $\mu \mathrm{mol} \mathrm{g}{ }^{-1}$ of tissue. The whole procedure was carried out under diffused light.

\section{Isozyme analysis}

The isoforms of POD were analysed in the crude enzyme extract prepared by homogenizing $1 \mathrm{~g}$ of tissue with $2 \mathrm{ml}$ of phosphate buffer $(0.1 \mathrm{M}, \mathrm{pH} 7.0)$, and centrifuging at $10,000 \mathrm{rpm}$ for $15 \mathrm{~min}$ at $4^{\circ} \mathrm{C}$. The supernatant was used as enzyme source. Enough volume of extract containing $25 \mu \mathrm{g}$ of protein was mixed with one-third volume of sample buffer $(10 \%$ glycerol containing bromophenol blue) and loaded over $7.5 \%$ native gel in case of cucumber and 5\% native gel in case of chilli. After electorophoresis, the gels were removed and rinsed with phosphate buffer (0.1 M, pH 5.6) for $30 \mathrm{~min}$ and immersed in $0.25 \%$ guaiacol in the same buffer and finally incubated in $0.15 \% \mathrm{H}_{2} \mathrm{O}_{2}$ until clear bands developed ${ }^{12}$.

The CAT isoforms were developed from the crude enzyme extract prepared by homogenizing $1 \mathrm{~g}$ of tissue with $2 \mathrm{ml}$ phosphate buffer $(0.1 \mathrm{M}, \mathrm{pH} 7)$ and centrifuging it at $10,000 \mathrm{rpm}$ for $15 \mathrm{~min}$ at $4^{\circ} \mathrm{C}$. The volume of extract containing $25 \mu \mathrm{g}$ of protein was mixed with one-third volume of sample buffer and loaded over $7.5 \%$ native gel. After electrophoresis, the gels were first incubated in $0.01 \% \mathrm{H}_{2} \mathrm{O}_{2}$ for $10 \mathrm{~min}$ and then in a mixture containing $25 \mathrm{ml}$ each of $2 \%$ ferric chloride and $2 \%$ potassium ferricyanide solution until yellow bands appeared over a dark green background ${ }^{13}$. 

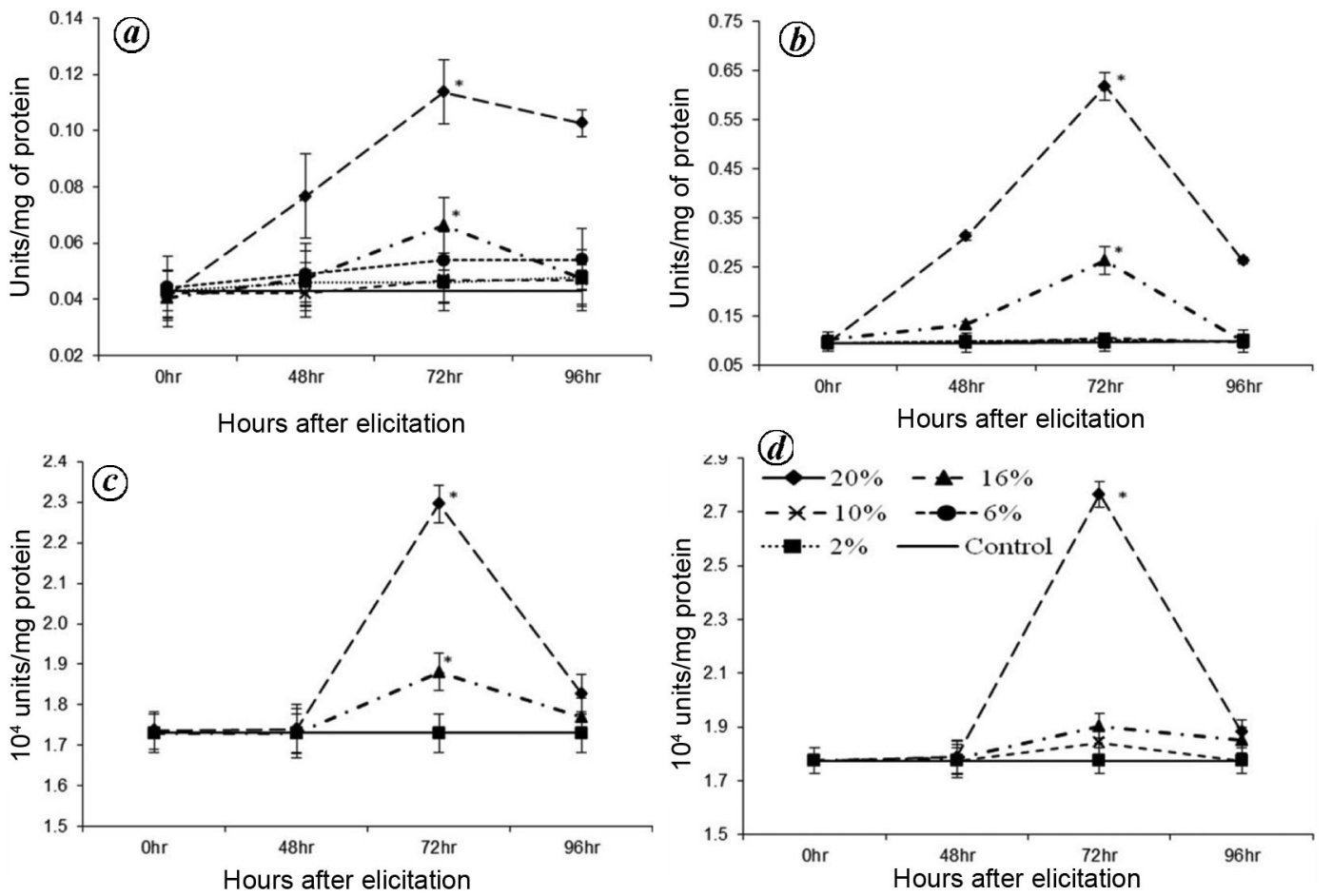

Figure 1. Induction of peroxidases (POD) and catalase (CAT) by the aqueous extract of Cleistanthus collinus in the seedlings. $\boldsymbol{a}, \boldsymbol{b}$, POD in hypocotyl of cucumber $(\boldsymbol{a})$ and cotyledonary leaves of chilli $(\boldsymbol{b})$. $\boldsymbol{c}, \boldsymbol{d}$, CAT in hypocotyl of cucumber $(\boldsymbol{c})$ and roots of chilli $(\boldsymbol{d})$. *Significant at $5 \%$ level of confidence according to Student's $t$-test.

\section{Statistical analysis}

Mean, standard error and Student's $t$ value were computed using MS-Excel and XL-STAT.

\section{Results}

Our previous study had reported induction of POD and CAT in the seedlings of cucumber and chilli by biotic and abiotic elicitors ${ }^{14}$. Here we undertook time-course study to determine the time needed by the enzyme to reach its peak activity after elicitation. We found that POD and CAT attained peak activity after $72 \mathrm{~h}$ of elicitation ${ }^{14}$. Therefore, in the present study we determined the activity of enzymes at $0,48,72$ and $96 \mathrm{~h}$ after elicitation with the plant extracts. The aqueous extracts of aerial parts of $A$. indica, C. procera, C. collinus, D. sissoo, D. inoxia and L. camara were sprayed at $2 \%, 6 \%, 10 \%, 16 \%$ and $20 \%$ concentration to elicit the seedlings. The effect varied according to the crop species, plant extract, concentration of the extract and seedling part. Irrespective of crop species, seedling part and plant extract, POD and CAT achieved peak activity after $72 \mathrm{~h}$ of elicitation (Figure 1 ). The extract of $C$. collinus induced significant activity of both enzymes in all parts of the seedlings of cucumber and chilli. The extracts of other plants, however, were sporadically active in enhancing enzyme activity (data not shown). Notably, $20 \%$ extract of all the plants increased the activity of CAT in chilli (Table 1). In gen- eral, $20 \%$ extract was the most effective in increasing the activity of enzymes, followed by $16 \%$ concentration. In contrast, the lower concentrations, i.e. $2 \%-10 \%$ could not enhance the activity of POD and CAT (data not shown).

Since $20 \%$ concentration was the most effective and peak activity was reached $72 \mathrm{~h}$ after elicitation, we compared the activity of POD and CAT induced by the $20 \%$ extract of all the plants after $72 \mathrm{~h}$ of elicitation. The results showed that the extract of $C$. collinus was markedly active in increasing enzyme, activity followed by C. procera (Table 1). A differential response of cucumber seedlings in inducing enzyme activity was obvious towards the plant extracts. While the extract of $C$. proce$r a$ increased the activity of POD to a maximum; $C$. collinus induced the activity of CAT to a maximum in cucumber seedlings (Table 1). In contrast, the extract of C. collinus induced maximum activity of POD in chilli seedlings (Table 1). However, the cotyledonary leaves, hypocotyl and roots of chilli seedlings responded differentially to plant extracts in inducing CAT activity. The extracts of $C$. collinus, L. camara and A. indica induced maximum activity of CAT in cotyledonary leaves, hypocotyl and roots of chilli seedling (Table 1).

The extract of $C$. collinus, was the most effective in inducing enzyme activity in cucumber and chilli seedlings. Therefore, in the next step we fractionated the extract of C. collinus over the silica gel column. We sequentially eluted the extract of $C$. collinus with $90 \%$ methanol (fraction 1), 45\% methanol (fraction 2) and distilled water 
RESEARCH ARTICLES

Table 1. Peak activities of enzymes in the seedlings elicited with $20 \%$ plant extract

\begin{tabular}{|c|c|c|c|c|c|c|c|c|c|c|c|c|}
\hline \multirow[b]{4}{*}{ Plant species } & \multicolumn{6}{|c|}{ Cucumber } & \multicolumn{6}{|c|}{ Chilli } \\
\hline & \multicolumn{3}{|c|}{$\begin{array}{c}\text { Peroxidases } \\
\text { (units/mg of protein) }\end{array}$} & \multicolumn{3}{|c|}{$\begin{array}{c}\text { Catalases } \\
\text { (units/mg of protein) }\end{array}$} & \multicolumn{3}{|c|}{$\begin{array}{c}\text { Peroxidases } \\
\text { (units/mg of protein) }\end{array}$} & \multicolumn{3}{|c|}{$\begin{array}{c}\text { Catalases } \\
\text { (units/mg of protein) }\end{array}$} \\
\hline & Cotyledonary & & & Cotyledonary & & & Cotyledonary & & & tyledona & & \\
\hline & leaves & Hypocotyl & Roots & leaves & Hypocotyl & Roots & leaves & Hypocotyl & Roots & leaves & Hypocotyl & Roots \\
\hline $\begin{array}{l}\text { Azadirachta } \\
\text { indica }\end{array}$ & 0.08 & 0.04 & 0.04 & 1.78 & 1.90 & 2.04 & 0.36 & 0.11 & 0.03 & 1.76 & 1.33 & 2.08 \\
\hline $\begin{array}{c}\text { Calotropis } \\
\text { procera }\end{array}$ & 0.58 & 0.18 & 0.11 & 1.50 & 1.54 & 1.50 & 0.45 & 0.16 & 0.06 & 1.23 & 1.53 & 2.04 \\
\hline $\begin{array}{l}\text { Cleistanthus } \\
\text { collinus }\end{array}$ & 0.44 & 0.11 & 0.04 & 2.50 & 2.30 & 2.20 & 0.61 & 0.20 & 0.19 & 2.07 & 1.53 & 2.04 \\
\hline Dalbergia sissoo & 0.11 & 0.06 & 0.02 & 1.30 & 1.63 & 1.56 & 0.11 & 0.06 & 0.04 & 1.26 & 1.53 & 2.04 \\
\hline Datura inoxia & 0.09 & 0.06 & 0.04 & 1.26 & 1.53 & 2.04 & 0.07 & 0.05 & 0.03 & 1.28 & 1.28 & 1.43 \\
\hline Lantana camara & 0.08 & 0.04 & 0.25 & 1.05 & 1.19 & 1.30 & 0.10 & 0.07 & 0.03 & 1.46 & 1.54 & 1.50 \\
\hline
\end{tabular}

(fraction 3). These solvents eluted $98.9 \%$ of the extract loaded onto the silica gel column ${ }^{7}$. The dried fractions were reconstituted with distilled water and used to elicit the seedlings of cucumber and chilli. The whole extract and fraction 1 actively enhanced the activity of POD and CAT in seedlings of both the crops after $72 \mathrm{~h}$ of elicitation. The other two fractions, could not induce POD and CAT activity (Figures 2 and 3 ).

Proving that elicitation of seedlings with fraction 1 induces activity of POD and CAT in seedlings prompted us to examine the effects of elicitation with fraction 1 in detail. The first aspect we studied was the effect of elicitation on the $\mathrm{H}_{2} \mathrm{O}_{2}$ content in seedling parts. $\mathrm{H}_{2} \mathrm{O}_{2}$ content in the seedlings after elicitation varied according to the crop species and seedling part. $\mathrm{H}_{2} \mathrm{O}_{2}$ content in the seedlings gradually increased till $70 \mathrm{~h}$ before subsiding at $75 \mathrm{~h}$ after elicitation (Figures 4 and 5). Such a trend was prominent in the cotyledonary leaves of cucumber where about $17 \%$ increase in $\mathrm{H}_{2} \mathrm{O}_{2}$ content was recorded (Figure $4 a$ ). Unlike cotyledonary leaves, $\mathrm{H}_{2} \mathrm{O}_{2}$ content in hypocotyl and roots of cucumber seedlings showed slight improvement after $70 \mathrm{~h}$ of elicitation. On the other hand, $\mathrm{H}_{2} \mathrm{O}_{2}$ content in chilli seedlings gradually increased after elicitation in cotyledonary leaves and roots till $70 \mathrm{~h}$ after elicitation. In contrast, $\mathrm{H}_{2} \mathrm{O}_{2}$ content in hypocotyl of chilli was almost unaffected till $60 \mathrm{~h}$ after elicitation. However, later a sudden upsurge in $\mathrm{H}_{2} \mathrm{O}_{2}$ content was recorded till $70 \mathrm{~h}$ after elicitation (Figure 5).

Since reactions catalysed by POD and CAT involve $\mathrm{H}_{2} \mathrm{O}_{2}$, we compared the peak activity of the enzymes with maximum $\mathrm{H}_{2} \mathrm{O}_{2}$ content recorded in the study in seedling parts (Figure 6). The comparison revealed the expected correlation between $\mathrm{H}_{2} \mathrm{O}_{2}$ content and enzyme activity. The seedling parts where the activity of POD was higher also had higher $\mathrm{H}_{2} \mathrm{O}_{2}$ content thus showing positive correlation between them (Figure $6 a$ ). In contrast, negative correlation between CAT activity and $\mathrm{H}_{2} \mathrm{O}_{2}$ content in the seedlings of cucumber and chilli was apparent (Figure $6 b$ ).
The second aspect about the effect of fraction 1 in seedlings of cucumber and chilli was the elucidation of qualitative change in the induction of POD and CAT. We developed the zymogram of each enzyme to achieve this objective. A remarkable change in the induction of isoforms of POD and CAT was evident from a study of isozyme profiles of the enzymes in seedling parts (Figures 7-10). The seedling parts of cucumber showed two heavy and a moderate-sized band corresponding to POD. However, on challenge with plant extract and fraction 1 , the isozyme profile was altered in the cotyledonary leaves and hypocotyl. The plant extract and fraction 1 induced an extra band each of heavy, moderate and lightweight in the cotyledonary leaves of cucumber (Figure $7 a$ ). In the same manner a single heavy isoform of POD was induced in the hypocotyl of cucumber by plant extract and fraction 1. In addition, elicitation with the plant extract and fraction 1 induced several moderate-sized isoforms of POD in the hypocotyl (Figure $7 b$ ).

Unlike cucumber, tissue-specific isoforms of POD were present in the seedling parts of chilli. The cotyledonary leaves of chilli had two heavy isoforms and one isoform each of moderate and lightweight (Figure $7 d$ ). In contrast, the hypocotyl of chilli had three heavy bands of POD isoforms and one isoform of moderate size (Figure $7 e$ ) and the roots of chilli had two heavy bands and one band each of moderate and lightweight (Figure 7f). Eliciting the seedling with plant extract and fraction 1 induced one moderate weight band in cotyledonary leaves of chilli. Also, elicitation with fraction 1 induced a heavy band of POD in cotyledonary leaves (Figure $7 d$ ). Similarly, elicitation also induced extra isoforms of POD in hypocotyl of chilli. While plant extract induced one lightweight band in hypocotyl, elicitation with fraction 1 induced two lightweight bands of POD (Figure $7 e$ ). Elicitation with plant extract and fraction 1 brought about the most significant changes in the zymogram of POD in the roots of chilli seedlings. First, the intensity of moderate 

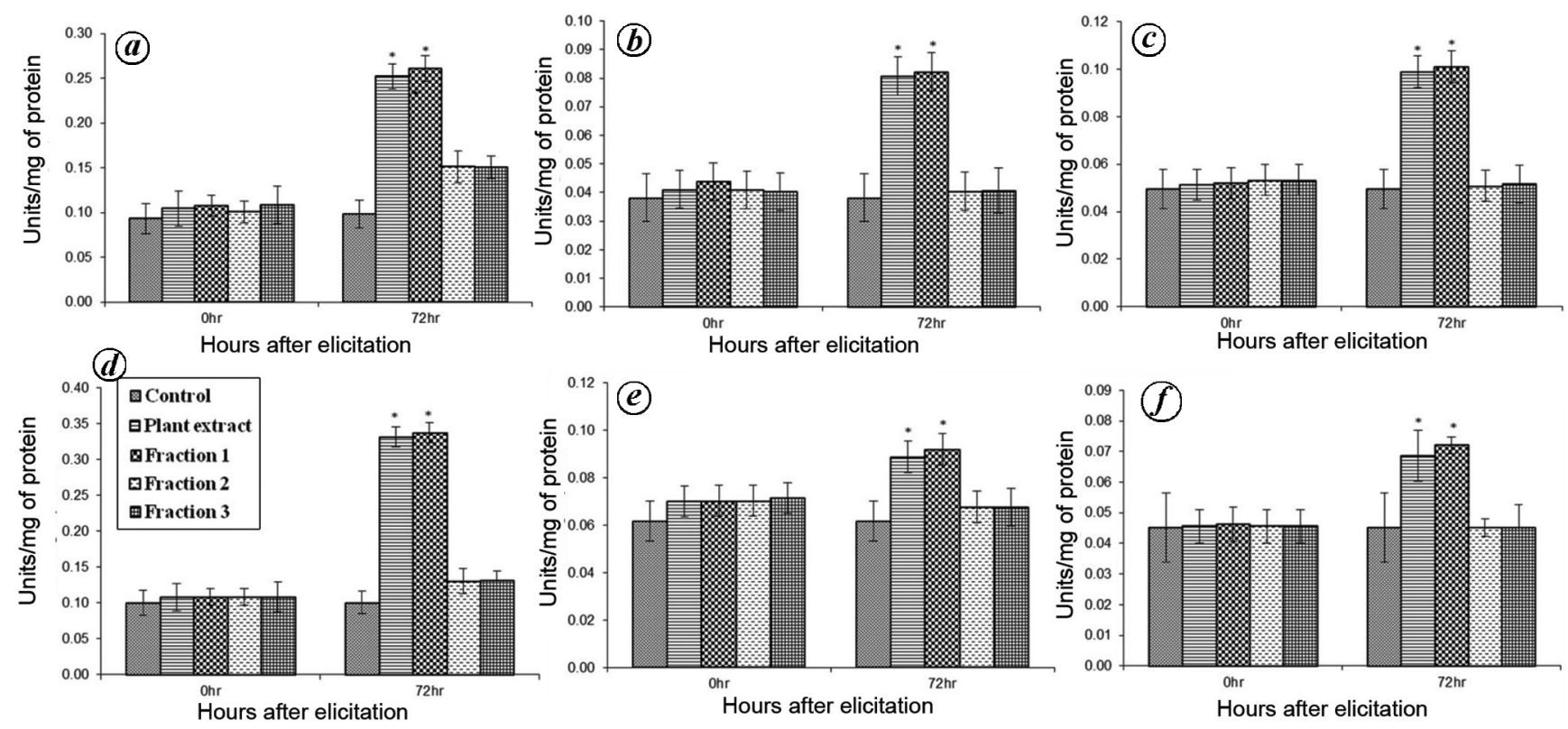

Figure 2. Induction of peroxidases by the aqueous extract of $C$. collinus and its fraction 1 in the seedlings of cucumber and chilli. $\boldsymbol{a}-\boldsymbol{c}$, Cucumber: $(\boldsymbol{a})$ cotyledonary leaves, $(\boldsymbol{b})$ hypocotyl and $(\boldsymbol{c})$ roots. $\boldsymbol{d}-\boldsymbol{f}$, Chilli: $(\boldsymbol{d})$ Cotyledonary leaves, $(\boldsymbol{e})$ hypocotyl and $(\boldsymbol{f})$ roots. $*$ Significant at $5 \%$ level of confidence according to Student's $t$-test.
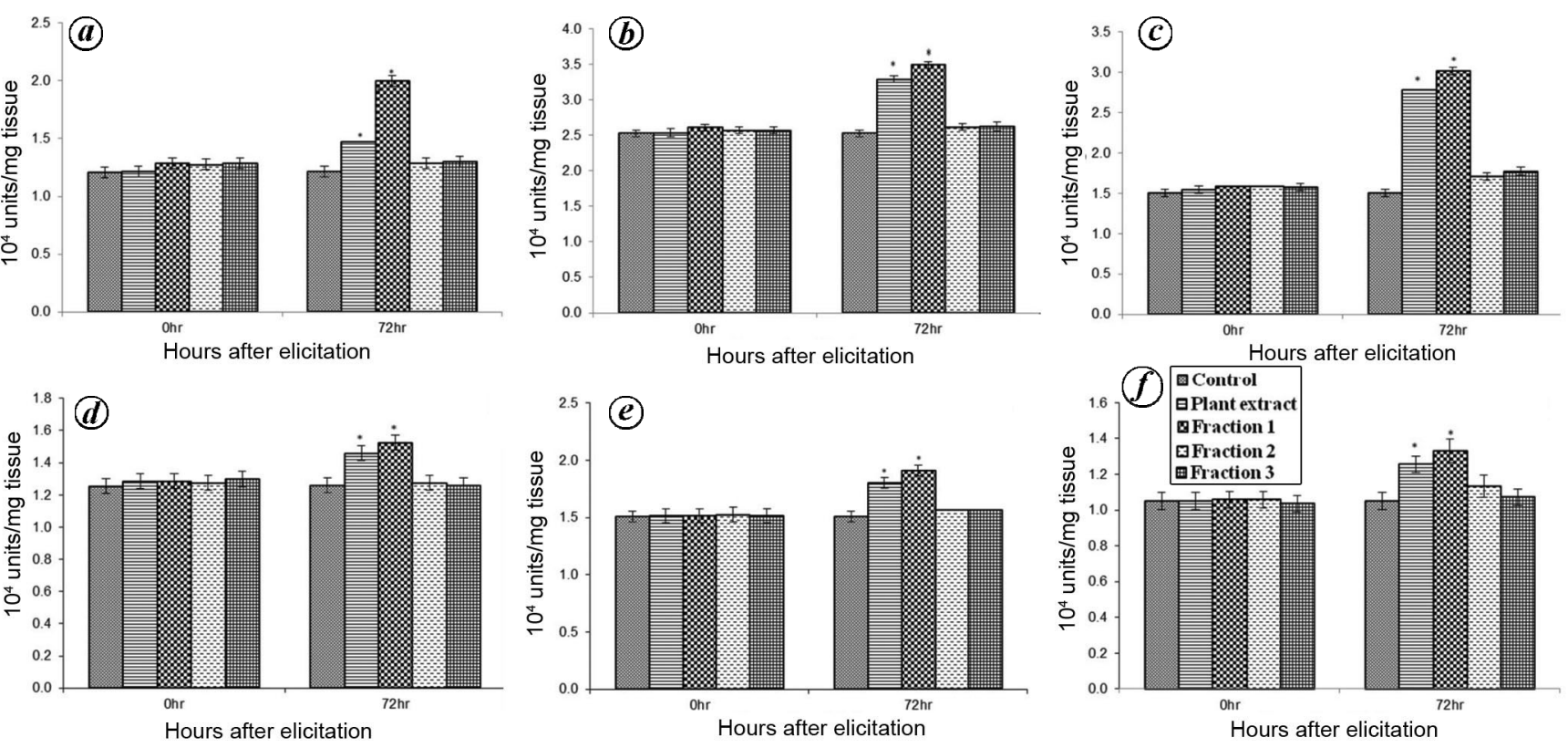

Figure 3. Induction of catalase by the aqueous extract of $C$. collinus and its fraction 1 in the seedlings of cucumber and chilli. $\boldsymbol{a}-\boldsymbol{c}$, Cucumber: (a) cotyledonary leaves, $(\boldsymbol{b})$ hypocotyl and $\boldsymbol{c}$, roots. $\boldsymbol{d}-\boldsymbol{f}$, Chilli: cotyledonary leaves, $(\boldsymbol{e})$ hypocotyl and $(\boldsymbol{f})$ roots. $*$ Significant at $5 \%$ level of confidence according to Student's $t$-test.

and lightweight bands increased prominently and second, elicitation induced an extra lightweight band in the roots of chilli (Figure $7 f$ ).

Similar to POD, obvious changes in the zymogram of CAT were noticed on elicitation with plant extract and fraction 1. However, unlike POD, the new isoforms of CAT were seldom induced. The cotyledonary leaves of cucumber showed the presence of one band each of heavy, moderate and lightweight. Notably, the moderate weight band occupied larger area than the other two bands. Elicitation of cucumber seedlings with plant extract further increased the area occupied by the moderate weight band. Strikingly, elicitation of cucumber seedling with fraction 1 induced an extra equally large moderate weight band in the cotyledonary leaves (Figure $8 a$ ). The hypocotyl and roots of cucumber showed a heavy weight band with a prominent moderate weight band in control. However, eliciting the seedlings with 

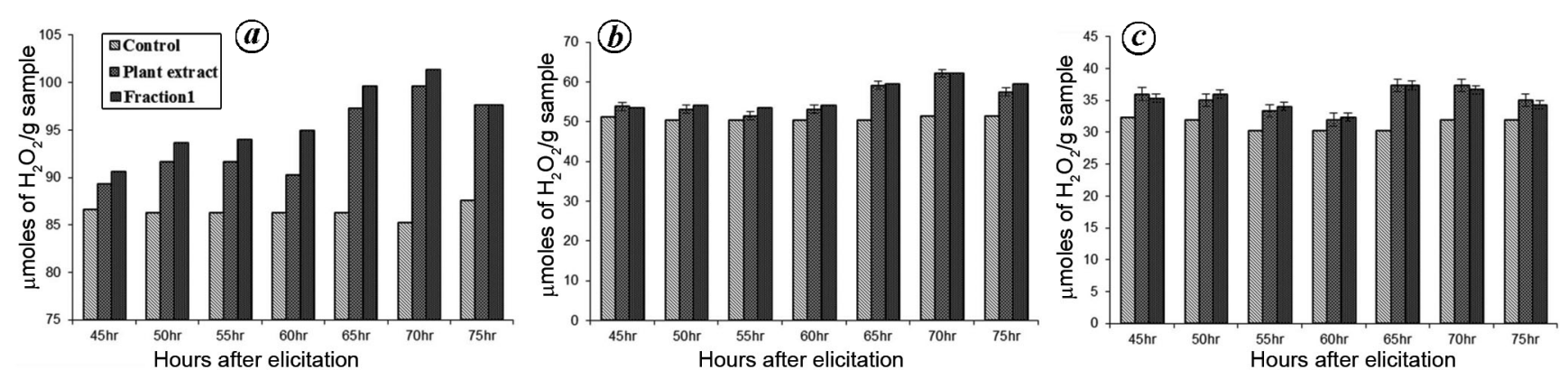

Figure 4. Hydroen peroxide $\left(\mathrm{H}_{2} \mathrm{O}_{2}\right)$ content in cucumber seedlings elicited with the aqueous extract of $C$. collinus and its fraction 1 . (a) Cotyledonary leaves; (b) hypocotyl and (c) roots.
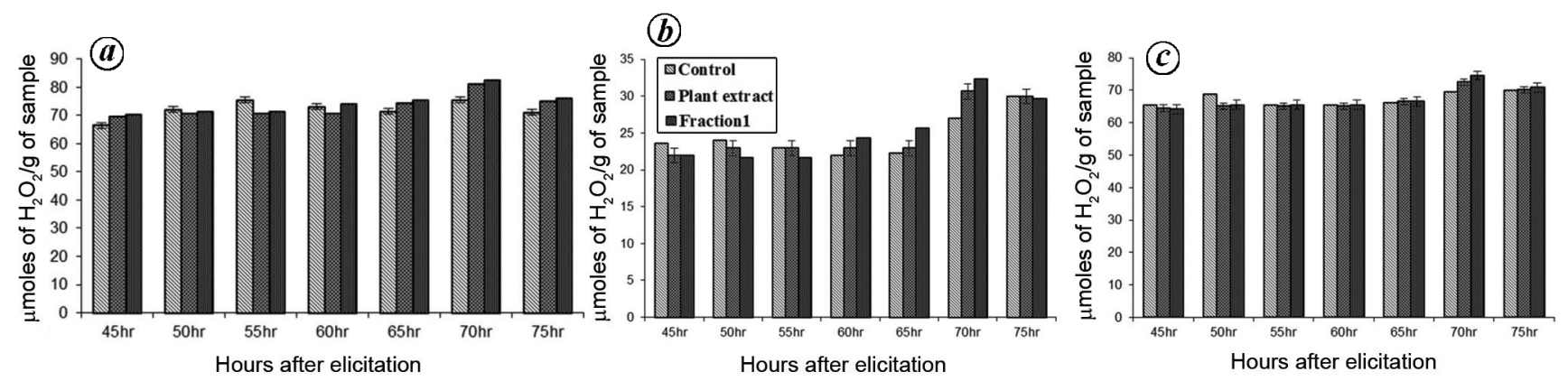

Figure 5. $\mathrm{H}_{2} \mathrm{O}_{2}$ content in chilli seedlings elicited with the aqueous extract of $C$. collinus and its fraction 1 . (a) Cotyledonary leaves, (b) hypocotyl and $(c)$ roots.

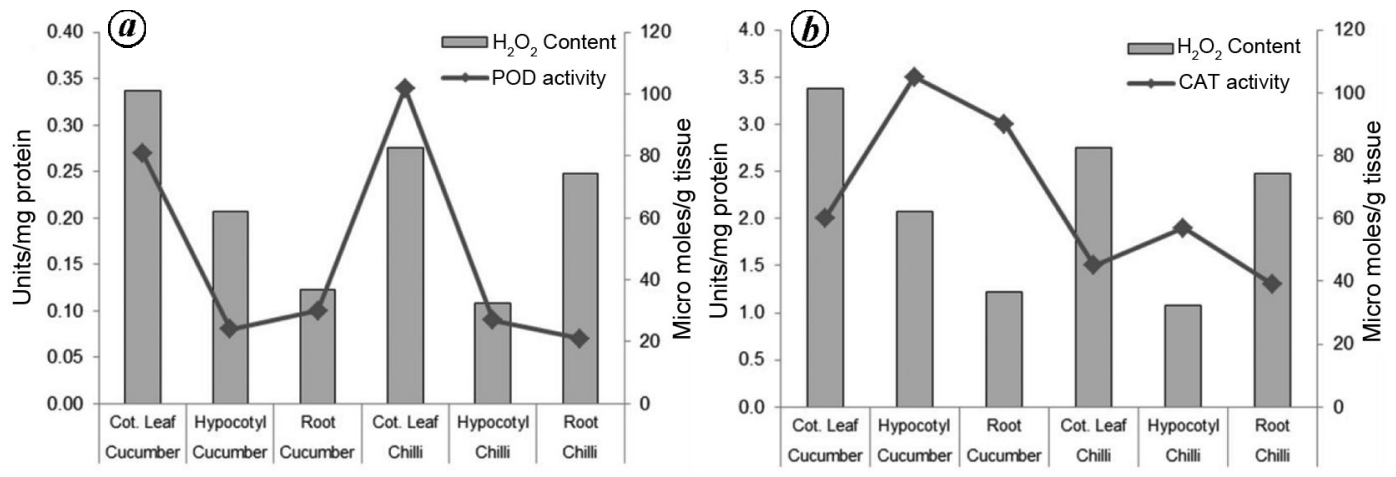

Figure 6. Correlation between enzyme activity and $\mathrm{H}_{2} \mathrm{O}_{2}$ content in the seedlings elicited with the extract of $C$. collinus. $\boldsymbol{a}$, Correlation with activity of peroxidases. $\boldsymbol{b}$, Correlation with activity of catalase.

plant extract and fraction 1 further increased the size of the moderate weight band. Besides, increase in the size of the moderate weight band in hypocotyl elicited with fraction 1 was more than that elicited with plant extract (Figure $8 b$ and $c$ ). The isozyme profile in cotyledonary leaves and roots of chilli seedlings was altered because of elicitation, whereas in hypocotyl it remained unaffected (Figure $8 d-f$ ). In control, the zymogram of cotyledonary leaves showed a heavy and a moderate weight band, with the latter covering larger area. Elicitation induced an extra heavy band by fraction 1 in cotyledonary leaves (Figure $8 d$ ). Similarly, the root of chilli showed presence of one band each of heavy and light weight, with the latter being larger. Elicitation with plant extract and frac- tion 1 increased the area occupied by the lightweight band. Also, area of the lightweight band was more in roots elicited with fraction 1 compared to those elicited with plant extract (Figure $8 f$ ).

\section{Discussion}

Use of plant extract as a natural plant defence inducer is worthwhile to prevent environmental and toxicological problems. Such products would have multiple benefits like eco-friendly nature, yield-boosting action, narrow target range, specific mode of action and low persistence in the environment ${ }^{15}$. Plants synthesize secondary 


\section{RESEARCH ARTICLES}

metabolites like phenols, phenolic acids, quinones, flavones, flavonoids, flavanols, tannins, coumarins, etc. These secondary metabolites are part of the defence mechanism of plants against pests and pathogens ${ }^{16}$. Besides, they are a rich source of bioactive compounds which can be used as novel crop-protecting agents.

The extracts of Zizyphus jujuba and Ipomoea carnea protect rice plants from Rhizoctonia solani by inducing defence enzymes like PAL, chitinases, $\beta-1,3$ glucanase, peroxidase and accumulating phenolics at a higher level ${ }^{17}$. Similarly, induction of antioxidant enzymes and resistance against Fusarium wilt in tomato seedlings on elicitation with aqueous extracts of neem and willow ${ }^{18}$, and increase in the activity of POD and CAT in rice by the extracts of Cymbopogon citrus and Ocimum sanctum $^{19}$ have also been reported. In the same line, increase in POD activity up to six days in the fruits of banana dipped in leaf extracts of Solanum torvum, Zimmu and A. alliaceum has been proved ${ }^{20}$. In conformation with earlier reports our study also revealed the induction of POD and CAT by extracts of $A$. indica, C. procera, C. collinus, $D$. sissoo, D. innoxia and L. camara. However, the ability to induce POD and CAT activity varied among the extracts. The qualitative and quantitative chemical analysis of the powder of plants selected for the study revealed the diversity of phytochemicals in them. C. collinus showed the presence of terpenoids, tannins, flavonoids, saponins, anthraquinones, coumarins and lignans, suggesting its richness in phytochemicals. C. collinus tested positive for lignans and negative for alkaloids. Similarly, cardiac glycosides were present only in D. sissoo, while tannins and coumarins were present in all the plant samples (data not shown). The quantitative analysis revealed that $C$. collinus had phenolic content much higher than the other plant samples. Similarly, D. sissoo and L. camara had higher content of carbohydrates and soluble proteins (data not shown). Therefore, the ability of plant extracts to induce POD and CAT activity in the seedlings of cucumber and chilli might be because of chemicals present in them ${ }^{20}$. However, differential activity of the extracts with respect to crop species and seedling parts was also evident. This might be because of (i) absence of the chemicals that can induce POD and CAT genes; (ii) presence of chemicals that can induce POD and CAT genes at suboptimal concentration, or (iii) differential distribution of cell-surface receptors over the seedlings ${ }^{7}$.

A difference of opinion exists among researchers about the role of POD in plant defence. While some argue for a

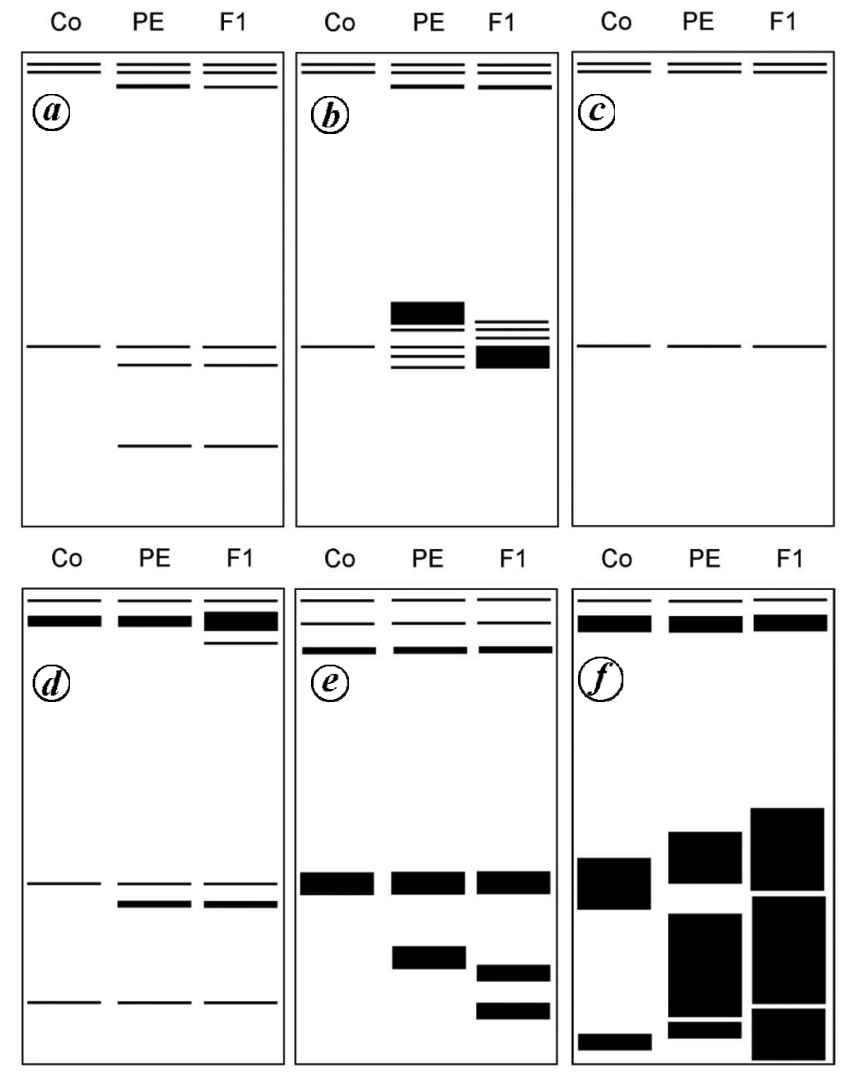

Figure 7. Peroxidase isoforms induced in the seedlings elicited with the aqueous extract of $C$. collinus and its first fraction. $\boldsymbol{a}-\boldsymbol{c}$, Cucumber: (a) Cotyledonary leaves, (b) hypocotyl and (c) roots. $\boldsymbol{d}-\boldsymbol{f}$, Chilli: $(\boldsymbol{d})$ Cotyledonary leaves, $(\boldsymbol{e})$ hypocotyl and $(\boldsymbol{f})$ roots. Co, Control; PE, Plant extract; F1, First fraction.

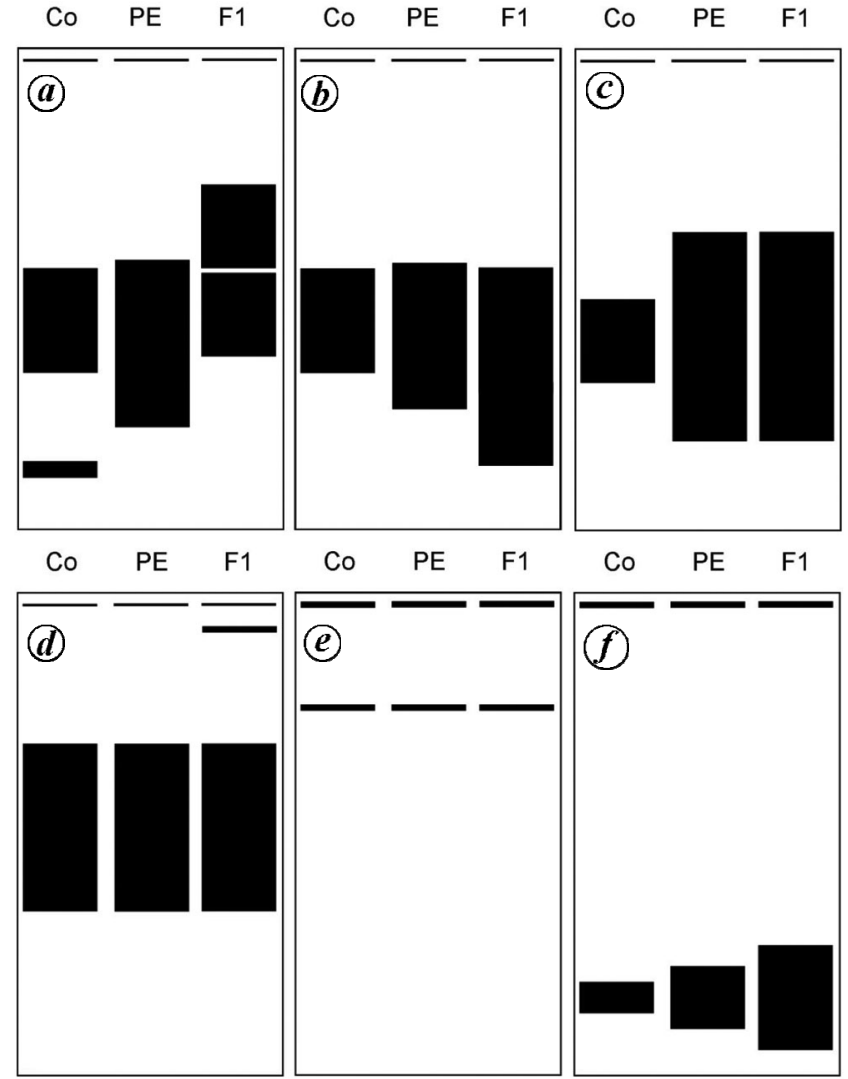

Figure 8. Catalase isoforms induced in the seedlings elicited with the aqueous extract of $C$. collinus and its first fraction. $\boldsymbol{a}-\boldsymbol{c}$, Cucumber: $(\boldsymbol{a})$ Cotyledonary leaves, $(\boldsymbol{b})$ hypocotyl and (c) roots. $\boldsymbol{d}-\boldsymbol{f}$, Chilli: $(\boldsymbol{d})$ Cotyledonary leaves, $(\boldsymbol{e})$ hypocotyl and $(\boldsymbol{f})$ roots. 


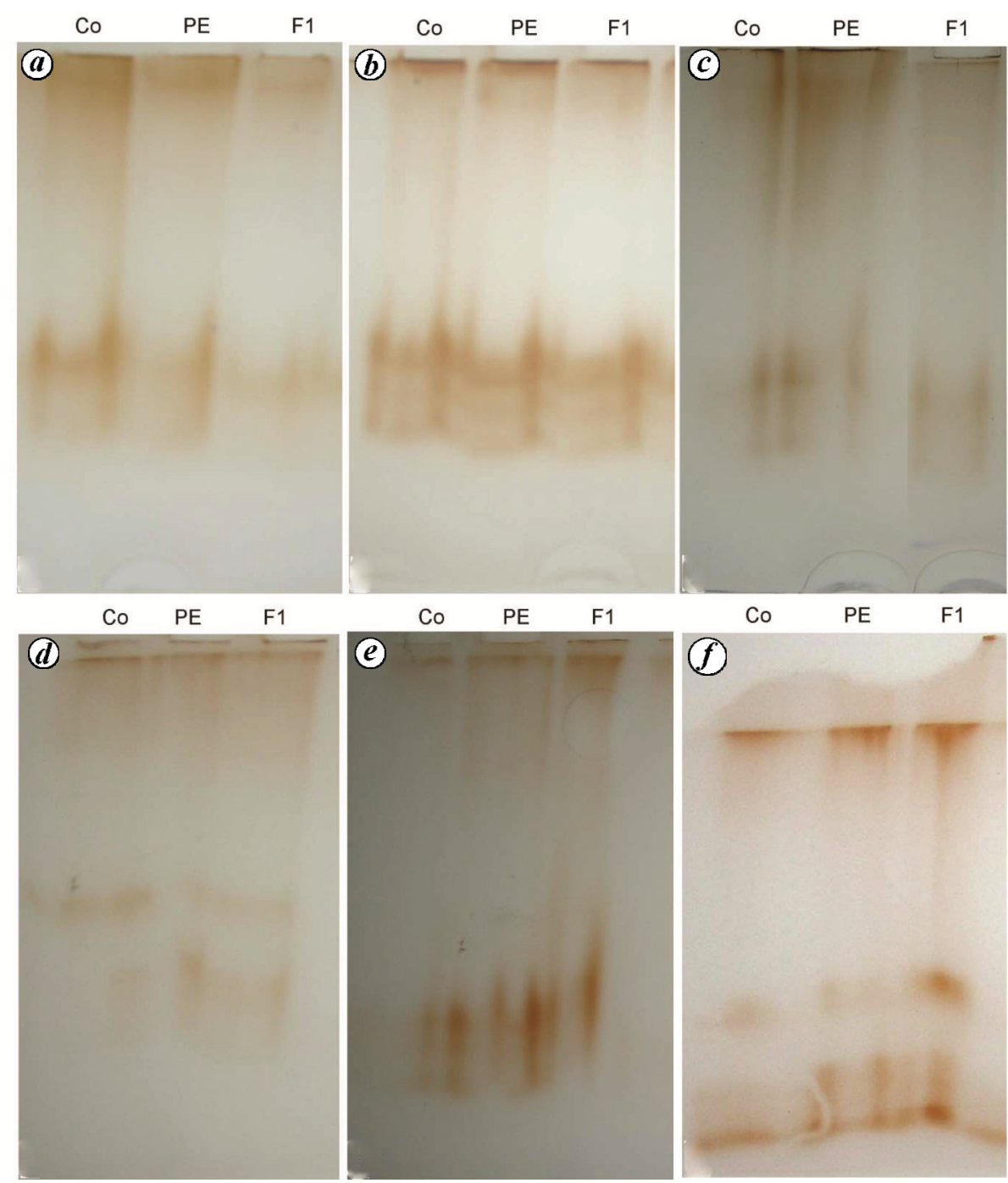

Figure 9. Gels showing peroxidase isoforms. $\boldsymbol{a}-\boldsymbol{c}$, Cucumber: (a) Cotyledonary leaves, (b) hypocotyl and $(\boldsymbol{c})$ root. $\boldsymbol{d}-\boldsymbol{f}$, Chilli: $(\boldsymbol{d})$ Cotyledonary leaves, $(\boldsymbol{e})$ hypocotyl and $(\boldsymbol{f})$ roots.

direct role of POD in defence reaction of plant resistance ${ }^{21}$, others regard POD activity as a biochemical marker which may not necessarily be a part of the resistance mechanism ${ }^{22,23}$. Metabolism continuously produces reactive oxygen species (ROS) such as superoxide radical, hydroxyl radical and $\mathrm{H}_{2} \mathrm{O}_{2}$ as by-products ${ }^{24}$. It has been proved that ROS, $\mathrm{H}_{2} \mathrm{O}_{2}$ in particular, are the components of early defence responses in plants, which include direct antimicrobial action, lignin formation, phytoalexin production and triggering $\mathrm{SAR}^{25}$. However, simultaneously ROS also harm the plant cells. When produced in excess, ROS cause oxidative damage of pigments, proteins, nucleic acids and lipids. Therefore, for normal plant growth, ROS should be maintained at sub-lethal level. To ensure this, plants have developed protective mechanisms against oxidative stress. These mechanisms use enzymatic and non-enzymatic molecules to scavenge the excess ROS. Enzymatic scavenging of ROS includes multiple antioxidant enzyme systems. For example, superoxide dismutase reacts with the superoxide radical to produce $\mathrm{H}_{2} \mathrm{O}_{2}$, which is scavenged by POD and CAT. The nonenzymatic constituents are tocopherol, ascorbate and reduced glutathione which remove or neutralize $\operatorname{ROS}^{26}$. In the present study, elicitation of seedlings with extract of $C$. collinus and its fraction 1 led to increase in $\mathrm{H}_{2} \mathrm{O}_{2}$ content. Therefore, the consequent increase in activity of POD and CAT because of elicitation probably is to scavenge the excess $\mathrm{H}_{2} \mathrm{O}_{2}$ from the cells.

Since the extract of $C$. collinus had a broad spectrum of activity, we decided to study its fractions eluted over silica gel column. Therefore, the extract of $C$. collinus was fractioned sequentially with $90 \%, 45 \%$ and $0 \%$ aqueous methanol. Only fraction 1 (eluted with 90\% methanol) showed bioactivity by inducing POD and CAT activity. Moreover, the bioactivity of fraction 1 was mostly higher than that of the plant extract. As stated earlier, bioactivity of plant extracts is due to the presence of certain chemicals in them, which can interact with the receptors over the 

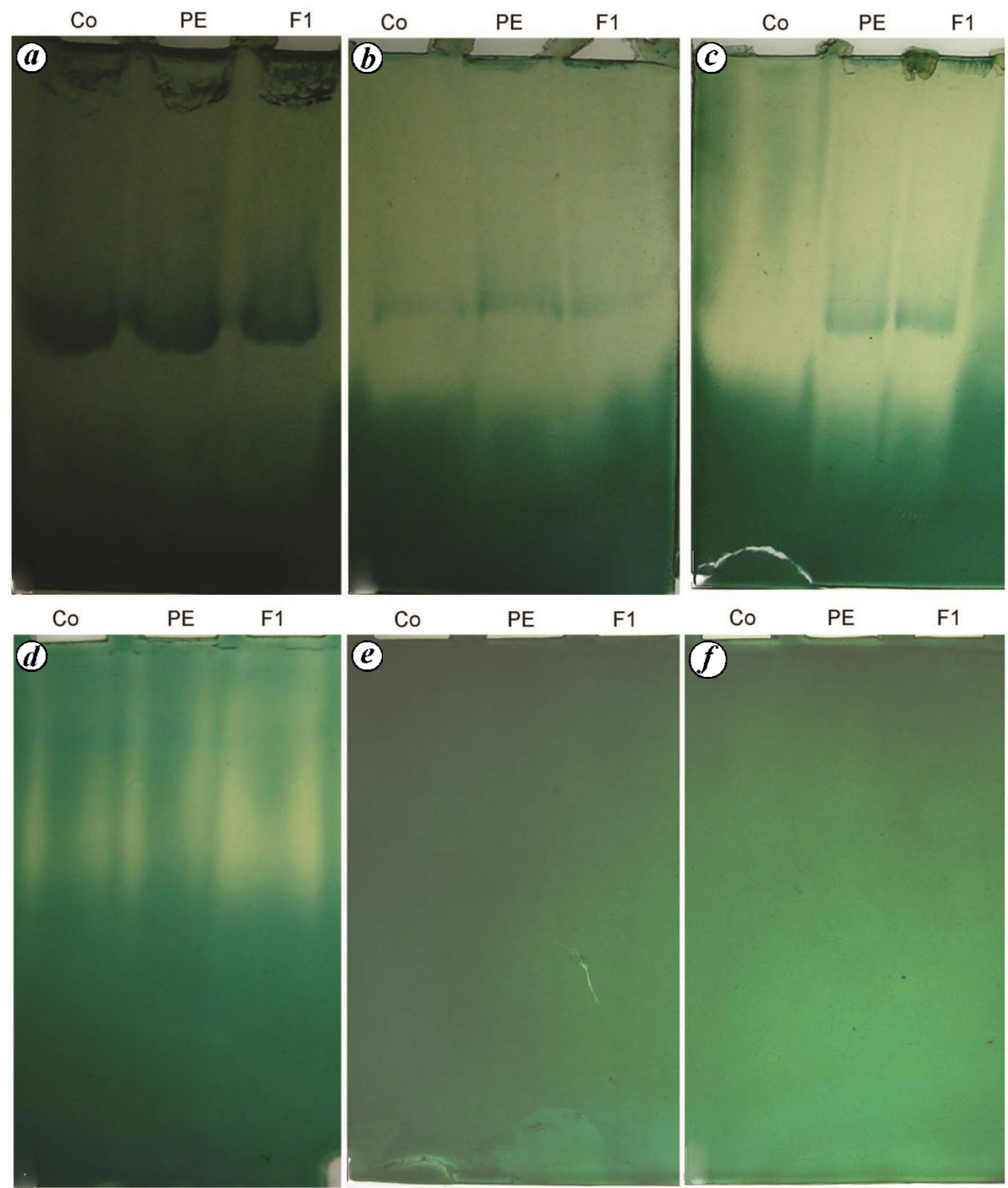

Figure 10. Gels showing catalase isoforms. $\boldsymbol{a}-\boldsymbol{c}$, Cucumber: (a) Cotyledonary leaves; (b) hypocotyl and $(\boldsymbol{c})$ roots. $\boldsymbol{d}-\boldsymbol{f}$, Chilli: $(\boldsymbol{d})$ Cotyledonary leaves, $(\boldsymbol{e})$ hypocotyl and $(\boldsymbol{f})$ roots.

cells and elicit response. Display of bioactivity exclusively by fraction 1 suggests that all the bioactive compounds were eluted in it, while the remaining two fractions contained none of the bioactive principles or they were present at suboptimal levels.

Considering the bioactivity of fraction 1 , we studied its effect in more detail. For this, we determined $\mathrm{H}_{2} \mathrm{O}_{2}$ accumulation by the seedlings and modulation of isozyme profile of the seedlings on elicitation with extract of $C$. collinus and fraction 1. Although the difference between the effect of plant extract and fraction 1 on $\mathrm{H}_{2} \mathrm{O}_{2}$ concentration in seedling was inconspicuous, the isozyme profiles induced by these two elicitors were noticeably different, at least occasionally. Moreover, the isoforms of POD and CAT were also tissue-specific. We have earlier reported the quantitative characterization of the extract of C. collinus and fraction 1 (ref. 7). Fraction 1 is richer compared with the plant extract in terms of carbohydrate and flavonoid content. In contrast, plant extract is richer in total protein and tannin content than fraction $1 . \mathrm{We}$ have also reported the TLC profile of alkaloids, sesquiterpene lactone, terpenoids, lignans, tannins, coumarins, flavonoids, phenylpropanoids, anthraquinones and saponins in the extract of $C$. collinus and fraction 1 . While the plant extract profile was mostly similar with that of fraction 1 ; certain derivatives of phytochemicals were unique to either of them ${ }^{7}$. Therefore, probably the quantitative and qualitative differences in phytochemicals of the C. collinus extract and its fraction 1 are responsible for induction of different isoforms of POD and CAT in the seedlings of cucumber and chilli.

$\mathrm{H}_{2} \mathrm{O}_{2}$ content in the seedlings elicited with $C$. collinus extract and its fraction 1 correlated with the POD and CAT activity. Elicitation or infection causes oxidative burst inside the cells ${ }^{27}$, which signals activation of defence genes ${ }^{28}$. The findings of the present study suggest activation of defence response in seedlings because of elicitation by extract of $C$. collinus and fraction 1 . Our 
earlier study on induction of the activity of $\beta-1,3$ glucanase and chitinases by the aqueous extract of $C$. collinus supports this assumption?

Further, in this study increase in $\mathrm{H}_{2} \mathrm{O}_{2}$ content in seedlings was observed after challenging with the extract of $C$. collinus and its fraction $1 . \mathrm{H}_{2} \mathrm{O}_{2}$ content increased after elicitation and then subsided after $70 \mathrm{~h}$, when the POD and CAT activity was at its peak. The initial increase in $\mathrm{H}_{2} \mathrm{O}_{2}$ content after elicitation is in agreement with the earlier findings, where such increase was observed on application of chemical agents in drought-stressed rice plants ${ }^{29}$. In the present study, the $\mathrm{H}_{2} \mathrm{O}_{2}$ content was inversely proportional to the CAT activity for which $\mathrm{H}_{2} \mathrm{O}_{2}$ is a substrate. A similar observation in barley roots under salt stress has been reported, where increased CAT activity led to decrease in $\mathrm{H}_{2} \mathrm{O}_{2}$ content ${ }^{30}$. Therefore, decrease in $\mathrm{H}_{2} \mathrm{O}_{2}$ content after $70 \mathrm{~h}$ of elicitation is obvious as CAT, which scavenges $\mathrm{H}_{2} \mathrm{O}_{2}$, is the most active. POD oxidizes the substrate in the presence of $\mathrm{H}_{2} \mathrm{O}_{2}$, which accepts the electron ejected by the substrate. This enables us to understand the direct correlation between POD activity and $\mathrm{H}_{2} \mathrm{O}_{2}$ content as the abundance of electron acceptor, i.e. $\mathrm{H}_{2} \mathrm{O}_{2}$, allows the enzyme to oxidize more substrate.

$\mathrm{H}_{2} \mathrm{O}_{2}$ is also involved in the development of SAR and pathogenesis related (PR) gene expression. BTH application resulted in accumulation of $\mathrm{H}_{2} \mathrm{O}_{2}$ (ref. 31). It was considered to be the downstream signal for SA in SAR and therefore, $\mathrm{H}_{2} \mathrm{O}_{2}$ serves as a secondary messenger in SAR signalling ${ }^{32,33}$. However, Ryals et al. ${ }^{34}$ did not support the view that $\mathrm{H}_{2} \mathrm{O}_{2}$ induces SAR. The claim that $\mathrm{H}_{2} \mathrm{O}_{2}$ induces SAR is supported by studies involving the treatment of tobacco lines with $\mathrm{H}_{2} \mathrm{O}_{2}$-producing compounds like paraquat and glycolate, which leads to accumulation of PR-1 protein ${ }^{32}$. It has been reported that $\mathrm{H}_{2} \mathrm{O}_{2}$ induces SA accumulation and conversely SA triggers $\mathrm{H}_{2} \mathrm{O}_{2}$ accumulation ${ }^{35}$. Thus, $\mathrm{SA}$ and $\mathrm{H}_{2} \mathrm{O}_{2}$ amplify each other forming a loop. This loop may produce microbursts that intensify and spread the $\mathrm{H}_{2} \mathrm{O}_{2}$ signal. The increased $\mathrm{H}_{2} \mathrm{O}_{2}$ content may suggest oxidative cell death and establish acquired resistance in plants ${ }^{36,37}$.

Several reports mention the change in isozyme profile of POD and CAT due to infection and application of plant extracts. Induction of POD isoforms in tobacco on infection by tobacco mosaic virus and its positive correlation with induced resistance have been established ${ }^{38}$. Similarly, variation in the expression of POD isoforms in tomato, cowpea and soybean by the application of Trichoderma asperellum ${ }^{39}$, carrot root extract ${ }^{40}$ and garlic extract ${ }^{41}$ respectively, has been reported.

\section{Conclusion}

The findings of present study establish the induction of POD and CAT by the aqueous extract of $C$. collinus. It further supports our earlier proposition that the bioactivity of C. collinus could be exploited for crop protection in the field ${ }^{7}$. However, a comprehensive field study is needed in this regard.

1. Govindappa, M., Umesha, S. and Lokesh, S., Adathoda vasica leaf extract induces resistance in rice against bacterial leaf blight disease (Xanthomonas oryzae pv. oryzae). J. Plant Physiol. Biochem., 2011, 3, 6-14.

2. Cawood, M. E., Pretorius, J. C., Visser, J. C. and Westhuizen, A. J. Vd., Induced gene expression in wheat seedlings treated with a crude extract of Agapanthus africanus L. prior to leaf rust infection. Afr. J. Biotechnol., 2013, 12, 2876-2883.

3. Jadesha, G., Haller, H., Modhe, M. K., Hubballi, M., Prabakar, K. and Prakasam, V., Role of plant extracts in inducing systemic acquired resistance in harvested banana against anthracnose disease. Ann. Biol. Res., 2012, 3, 5413-5419.

4. Nguyen, D. M., Seo, D. J., Park, R. D., Lee, B. R. and Jung, W. J., Changes in antioxidative enzyme activities in cucumber plants with regard to biological control of root-knot nematode, Meloidogyne incognita with Cinnamomum cassia crude extracts. J. Korean Soc. Appl. Biol. Chem., 2011, 54, 507-514.

5. Kushnereva, V., Breeding of cucumber (Cucumis sativus) for resistance to multiple diseases and other traits. In Cucurbitaceae 2008, Proceedings of the IX EUCARPIA Meeting on Genetics and Breeding of Cucurbitaceae (ed. Pitrat, M.), Avignon, France, 2008, pp. 429-432.

6. Than, P. P., Prihastuti, H., Phoulivong, S., Taylor, W. J. and Hyde, K. D., Chilli anthranose disease caused by Colletotrichum species. J. Zhejiang Univ. Sci., 2008, 9, 764-778.

7. Kadoo, M. R. and Badere, R. S., Modulation of the activity of chitinases and $\beta-1,3$ glucanase in seedlings of cucumber and chilli by the aqueous extract of Cleistanthus collinus. Physiol. Mol. Plant Pathol., 2017, 98, 46-53; doi:http://dx.doi.org/10.1016/j.pmpp. 2017.03.004.

8. Kadoo, M. R. and Badere, R. S., Induction of chitinases and $\beta-1,3$ glucanase in the seedlings of Cucumis sativus and Capsicum annuum. Bioinfolet., 2014, 11(4B), 1165-1170.

9. Sadasivam, S. and Manickam, A., Biochemical Methods, New Age International (P) Limited, New Delhi, 1996.

10. Bradford, M. M., A rapid and sensitive method for the quantification of microgram quantities of protein utilizing the principle of protein dye binding. Anal. Biochem., 1976, 72, 1151-1154.

11. Velikova, V., Yoranov, I. and Edreva, A., Oxidative stress and some antioxidant systems in acid rain-treated bean plants: protective roles of exogenous polyamines. Plant Sci., 2000, 151, 59-66.

12. Hislop, E. C. and Stachmann, M. A., Peroxidase and ethylene production by barley leaves infected with Erysiphe graminis f. sp. hordei. Plant Pathol., 1971, 1, 297-312.

13. Woodbury, W., Spencer, A. K. and Stahman, M. A., An improved procedure using ferricyanide for detecting catalase isozymes. Anal. Biochem., 1971, 44, 301-305.

14. Kadoo, M. R. and Badere, R. S., Peroxidases and catalase activities in the seedlings of cucumber and chilli. Bioinfolet, 2016, 13(1B), 139-144.

15. Pretorius, J. C. and Sooth, Z. A., Extracts and compounds from Tulbaghia violacea and their use as biological plant protecting agents. 2014, United States Agrarforum AG (Bomlitz, D. E.), Agrarforum SA (Pty) Ltd., Bloemfontein, ZA, 8697149; http://www.freepatentsonline.com/8697149.html; freepatentsonline.com/8697149.html

16. Cowan, M., Plant products as antimicrobial agents. Clin. Microbiol., 1999, 12, 564-582.

17. Kagale, S., Marimuthu, T., Kagale, J., Thayumanvan, B. and Samiyappan, R., Induction of systemic resistance in rice by leaf 
extracts of Zizyphus jujuba and Ipomoea carnea against Rhizoctonia solani. Plant Signal. Behav., 2011, 6, 919-923.

18. Hanaa, R. M. F., Abdou, Z. A., Salama, D. A., Ibrahim, M. A. R. and Sror, H. A. M., Effect of neem and willow aqueous extracts on Fusarium wilt disease in tomato seedlings: induction of antioxidant defensive enzymes. Ann. Agric. Sci., 2011, 56, 1-7.

19. Pal, T. K., Bhattacharya, S. and Chakraborty, K., Induction of systemic resistance in rice by leaf extracts of Cymbopogon citrus and Ocimum sanctum against sheath blight disease. Arch. Appl. Sci. Res., 2011, 3, 392-400.

20. Shi, Q., Ding, F., Wang, X. and Wei, M., Exogenous nitric oxide protects cucumber roots against oxidative stress induced by salt stress plant. Physiol. Biochem., 2007, 45, 542-550.

21. Peng, M. and Kuc, J., Peroxidase-generated hydrogen peroxide as a source of antifungal activity in vitro on tobacco leaf disks. Phytopathology, 1992, 82, 696-699.

22. Shimoni, M. and Reuveni, R., A method for staining and stabilizing peroxidase activity in polyacrylamide gel electrophoresis. Anal. Biochem., 1988, 175, 35-38.

23. Reuveni, M., Agapov, V. and Reuveni, R., Induced systemic protection to powdery mildew in cucumber plants by phosphate and potassium salts: effect of inoculum concentration and post inoculation treatment. Can. J. Plant Pathol., 1995, 17, 247-251.

24. Gill, S. S. and Tuteja, N., Reactive oxygen species and antioxidant machinery in abiotic stress tolerance in crop plants. Plant Physiol. Biochem., 2010, 48, 909-930.

25. Mehdy, M. C., Active oxygen species in plant defense against pathogens. Plant Physiol., 1994, 105, 467-472.

26. Foyer, C. H., Lopez-Delgado, H., Dat, J. F. and Scott, I. M., Hydrogen peroxide and glutathione associated mechanisms of acclimatory stress tolerance and signalling. Physiol. Plant Pathol., 1997, 100, 241-254.

27. Apostol, I., Heinstein, P. F. and Low, P. S., Rapid stimulation of oxidative burst during elicitation of cultured plant cells. Plant Physiol., 1989, 90, 109-116.

28. Wojtaszek, P., Oxidative burst: an early plant response to pathogen infection. Biochem. J., 1997, 322, 681-692.

29. Shehab, G. G., Ahmed, O. K. and El-Beltagi, H. S., Effects of various chemical agents for alleviation of drought stress in rice plants (Oryza sativa L.). Notulae Bot. Horti Agrobota. ClujNapoca, 2010, 1, 139-148.

30. Kim, S. Y. et al., Enhanced antioxidant enzymes are associated with reduced hydrogen peroxide in barley roots under saline stress. J. Biochem. Mol. Biol., 2004, 38, 218-224.
31. Gondim, D. M. F., Terao, D., Martins-Miranda, A. S., Vasconcelos, I. M. and Oliveira, J. T. A., Benzo-thiadiazole-7-carbothioic acid $S$-methyl ester does not protect melon fruits against Fusarium pallidoroseum infection but induces responses in melon seedlings. J. Phytopathol., 2008, 156, 607-614.

32. Chen, Z. and Klessig, D. F., Identification of a soluble salicylic acid-binding protein that may function in signal transduction in the plant disease-resistance response. Proc. Natl. Acad. Sci. USA, 1991, 88, 8179-8183.

33. Chen, Z., Silva, H. and Klessig, D. F., Involvement of reactive oxygen species in the induction of systemic acquired resistance by salicylic acid in plants. Science, 1993, 242, 883-886.

34. Ryals, J. et al., Signal transduction in systemic acquired resistance. Proc. Natl. Acad. Sci. USA, 1995, 92, 4202-4205.

35. Leon, J., Lawton, M. A. and Raskin, $\mathrm{I}_{\text {., }} \mathrm{H}_{2} \mathrm{O}_{2}$ stimulates salicylic acid biosynthesis in tobacco. Plant Physiol., 1995, 108, 16731678.

36. Alvarez, M. E., Pennell, R. I., Meijer, P. J., Ishikawa, A., Dixon, R. A. and Lamb, C. J., Reactive oxygen intermediates mediate a systemic signal network in the establishment of plant immunity. Cell, 1998, 92, 773-784.

37. VanCamp, W., Montagu, M. V. and Inze, D., $\mathrm{H}_{2} \mathrm{O}_{2}$ and NO: redox signals in disease resistance. Trends Plant Sci., 1998, 3, 330-334.

38. Ye, X. S., Pan, S. Q. and Kuc, J., Activity, isozyme pattern, and cellular localization of peroxidase as related to systemic resistance of tobacco to blue mold (Peronospora tabacina) and to tobacco mosaic virus. Physiol. Biochem., 1990, 80, 1295-1299.

39. Murthy, K. N., Uzma, F. and Srinivas, C., Induction of systemic resistance by Trichoderma asperellum against bacterial wilt of tomato caused by Ralstonia solanacearum. Int. J. Adv. Res., 2013, 1, 181-194.

40. Abbas, S. M. and Akladious, S. A., Application of carrot root extract induced salinity tolerance in cowpea (Vigna sinensis L.) seedlings. Pak. J. Bot., 2013, 45, 795-806.

41. Mohamed, H. I. and Akladious, S. A., Influence of garlic extract on enzymatic and non enzymatic antioxidants in soybean plants (Glycine max) grown under drought stress. Life Sci. J., 2014, 11, $46-58$.

Received 20 May 2019; revised accepted 11 December 2019

doi: $10.18520 / \mathrm{cs} / \mathrm{v} 118 / \mathrm{i} 6 / 920-930$ 